\title{
Clinicopathological Evaluation of Disseminated Metastases of Transmissible Venereal Tumor in a Spayed Bitch
}

\author{
Hasan Alkan' ${ }^{1}$ Fatma Satilmis ${ }^{1}$, Mehmet Eray Alcigir ${ }^{2}$, Mehmet Bugra Kivrak ${ }^{3}$ \& Ibrahim Aydin ${ }^{1}$
}

\begin{abstract}
Background: Although transmissible venereal tumor (TVT, transmissible venereal sarcoma, Sticker's sarcoma) that affects dogs and other canids can be seen in many countries, it especially emerges in the countries which homeless dog population is very high. Female dogs are more susceptible than males. Transmissible venereal tumor is usually transmitted to genital organs during coitus and occasionally by social behavior such as sniffing and licking. The tumor is generally observed in the posterior part of the vagina. The tumor usually appears in various sizes, in the appearance of cauliflower, red and fragile. Metastases are rarely reported in cases with TVT. Metastases have been detected in lung, liver, tonsils, skin, lymph nodes, muscles, spleen. The diagnosis of transmissible venereal tumor is achived by considering the history of the animal, gross lesions, cytological examination and histopathology. Chemotherapy is frequently used in the treatment of TVT. In addition, radiotherapy, cryosurgery, surgical incision and immunotherapy are rarely applied for treatment. Chemical agents such as doxorubicin, vincristine sulfate, cyclophosphamide, methotrexate are preferred for chemotherapy.

Case: Metastases to all mammary lobes, cervix uteri, neck, skin, gluteal muscles, the oropharyngeal region, and primary vaginal mass were described in spayed bitch, a 10-year old and mixed breed. The clinical examination manifested, fragile and hemorrhagic masses which resemble cauliflower in the vagina, neck, and inguinal region. Furthermore firm and multilobular masses in all mammary lobes, oropharyngeal region, and gluteal muscles of right leg were detected. Firstly, vaginal cytology was performed in order to confirm. In vaginal cytology, round to polyhedral shaped transmissible venereal tumor cells including cytoplasmic vacuoles and polychromatic nuclei were identified. Histopathologically, solid areas included oval- to round-shaped cells with prominent, hyperchromatic nuclei in all masses. Also, some of them comprised mitotic figures in their nuclei. In general, the tumor cells were separated by thin fibrous septa. Additionally, the cells were completely infiltrated to the mammary gland. In contrast, oropharyngeal and subdermal region of neck consisted more solid areas under the epidermis. There was lymphocyte infiltration at the periphery of the cells. For gluteal mass, TVT cells were confined in muscle bundles. Transmissible venereal tumor cases are often located in genital organs and their metastases are rarely encountered in comparison with other tumors. In this case report, metastases to cervical tissue, neck skin, oropharyngeal mucosa and gluteal muscles, mammary lobes are found.

Discussion: When the sexual activity is high, the incidence of TVT increases. It especially develops in bitches in estrus. Breed, sex and age are not a cause of predisposition for TVT. Transmissible venereal tumors' malignancy can increase in some cases, although TVT is known as a benign tumor. Prevalence of metastases was found fairly low in the studies. Metastases to mammary region, to subcutaneous region, to brain, to eye, to lung, to uterus, to ovary, to liver, to spleen have been reported. In conclusion, even if a bitch is acyclic, transmissible venereal tumor can be developed and thus the risk of its disseminated metastasis must be considered. Moreover, since the masses have not regresed for a long time, this situation may be related to severe immunosupression in the bitch.
\end{abstract}

Keywords: bitch, clinicopathology, transmissible venereal tumor, disseminated metastases. 


\section{INTRODUCTION}

Although transmissible venereal tumor (TVT, transmissible venereal sarcoma, Sticker's sarcoma) that affects dogs and other canids can be seen in many countries, it especially emerges in the countries which homeless dog population is very high. Moreover, TVT occurs predominantly in tropical and subtropical regions [13-15].

The incidence of TVT in males and females is the same but the number of TVT cases in younger and sexually active ones outweighs $[10,14]$. TVT is usually transmitted to genital organs during coitus and occasionally by social behavior such as sniffing and licking $[3,15]$. Swelling of the penis in vagina and efforts of male to finish sexual intercourse cause contussion in genital organs. As a result of these traumas exfoliated neoplastic cells transplant the wounded tissue $[2,14]$.

In dogs of both sexes, the tumor usually locates in external genital organs. In males, it is commonly observed in preputium, the glans and caudal part of the penis. In females, the tumor locates in vulva, the junction of vestibule and vagina. TVT can occur as a solitary mass or multiple masses. A tumor which has a cauliflower-like appearance can be observed macroscopically fragile, hemorrhagic, and ulcerative $[8,15]$.

Metastases have been reported in 5-17\% of all cases. They are more frequent in males (16\%) than females (2\%) [9]. Metastases have been detected in lymph nodes, lung, tonsils, liver, spleen, skin $[4,5,10,16]$.

\section{CASE}

A 10-year old, mix breed bitch weighing 33 $\mathrm{kg}$, spayed 5 years ago which was brought to Selcuk University Faculty of Veterinary Medicine with a complaint of hemorrhagic vaginal discharge and swelling in mammary lobes constitutes of this case's material.

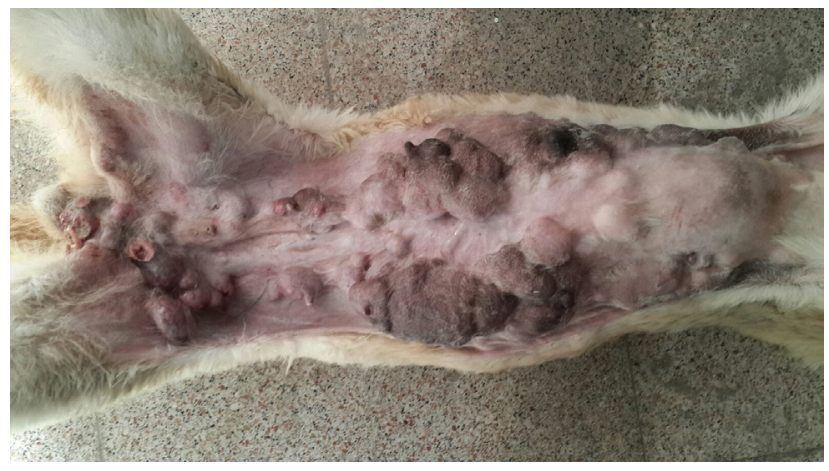

Figure 1. Disseminated metastases.
In clinical examination, anorexia, weight loss, dysphagia, and lameness were observed. Fragile and hemorrhagic masses which resemble cauliflower were detected in the vagina, neck, and inguinal region. Furthermore firm and multilobular masses in all mammary lobes, oropharyngeal region, and gluteal muscles of the rear right leg were detected (Figures 1-2). Vaginal cytology was performed in order to evaluate masses in the vagina. Specific TVT cells were detected by vaginal cytology (Figure 10). Vaginal cytology was stained according to May-Grünwald-Giemsa staining. Also, complete blood cell count, bloodgasses, and serum biochemical parameters were measured (Tables 1 \& 2). In an attempt to detect the reason of lameness an x-ray image of the rear right leg was taken (Figure 3). Moreover, in abdominal ultrasonography, a mass was observed close to the bladder (Figure 4). Because of poor prognosis the bitch has been euthanized with the full permission of the owner.

The necropsy was performed after euthanasia. In necropsy, fragile and hemorrhagic masses the size of which are $3 \times 4 \times 4 \mathrm{~cm}$ in the neck and $4 \times 3.5 \times 3 \mathrm{~cm}$ in the vagina were detected. Lobes size of masses is changing between 4-12 cm mass in mammary, a $1 \times 3 \times 0.5 \mathrm{~cm}$ mass in the oropharyngeal region, another $3 \times 2 \times 2.5 \mathrm{~cm}$ size in the gluteal muscles, and a $3 \times 4 \times 2.5 \mathrm{~cm}$ mass that is firm, solid and demarcated around cervix uteri were detected. On the other hand, ovarium and uterus was not able to find during necropsy.

Samples have collected from all the tissues which mass located in necropsy. All masses collected from the body were multilobular and grayish-pink colored. The collected tissue samples were fixed in $10 \%$ formalin, processed routinely and embedded in paraffin. Paraffin blocks were sectioned at 5 micrometers in thickness and stained with Haematoxylin-Eosin (H\&E) staining.

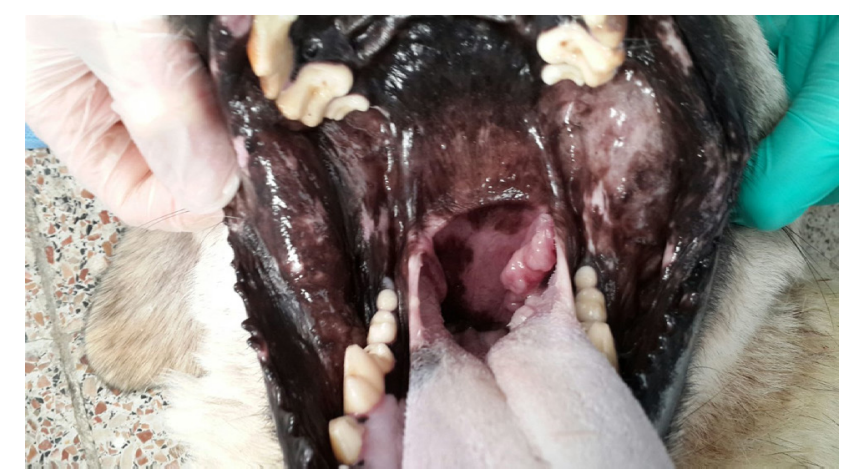

Figure 2. Oropharyngeal mass. 
H. Alkan, F. Satilmis, M.E. Alcigir, M.B. Kivrak \& I. Aydin. 2017. Clinicopathological Evaluation of Disseminated Metastases of Transmissible Venereal Tumor in a Spayed Bitch.

Cytologically, a large number of round-shaped cells having cytoplasmic vacuolation and, single prominent nucleoli also lymphocytes were observed (Figure 9). Histopathologically, oval to round shaped cells had prominent and polychromatic nuclei. Some of them comprised mitotic figures in their nuclei. The solid areas composed of the TVT cells were separated by thin fibrous stroma. Additionally, the cells were completely infiltrated to the mammary gland (Figure 8 ). In contrast to that oropharyngeal and subdermal region of neck consisted more solid areas under the epidermis (Figures $5 \& 6$ ). There was lymphocyte infiltration at the periphery of the cells. For gluteal mass, TVT cells were confined in muscle bundles (Figure 7).

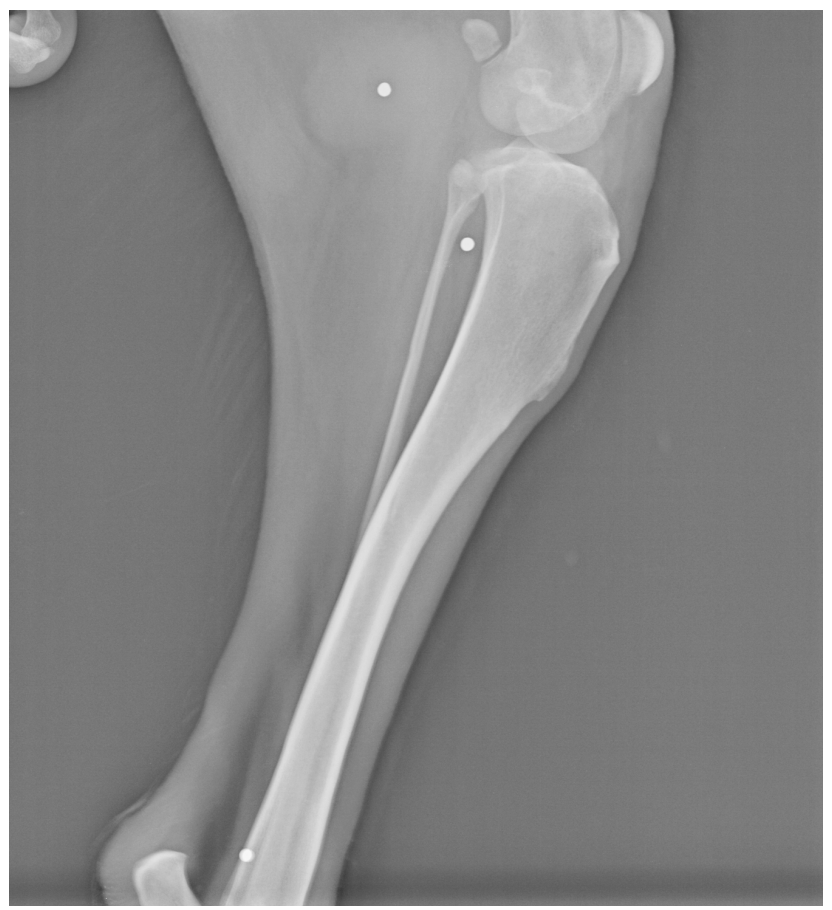

Figure 3. Image x-ray of right rear leg.

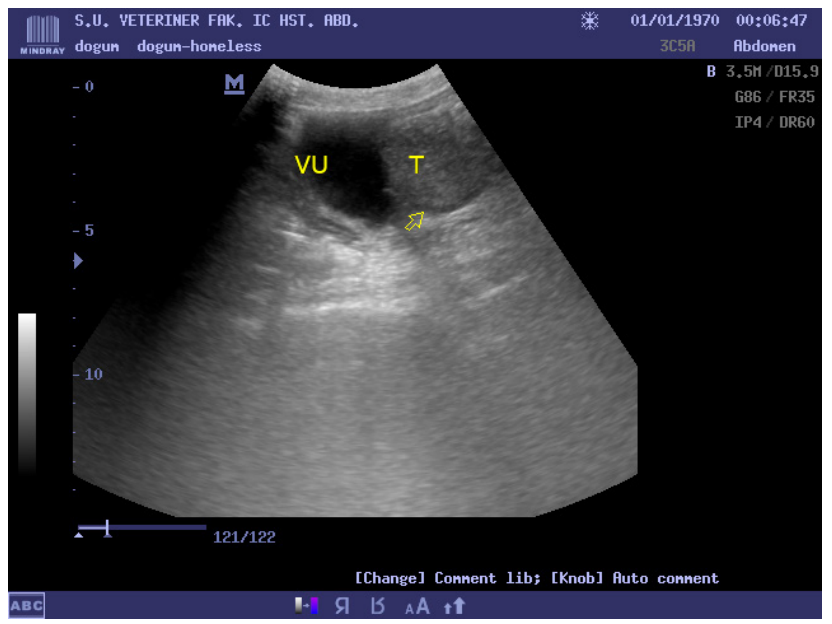

Figure 4. Image of the mass in front of the bladder.

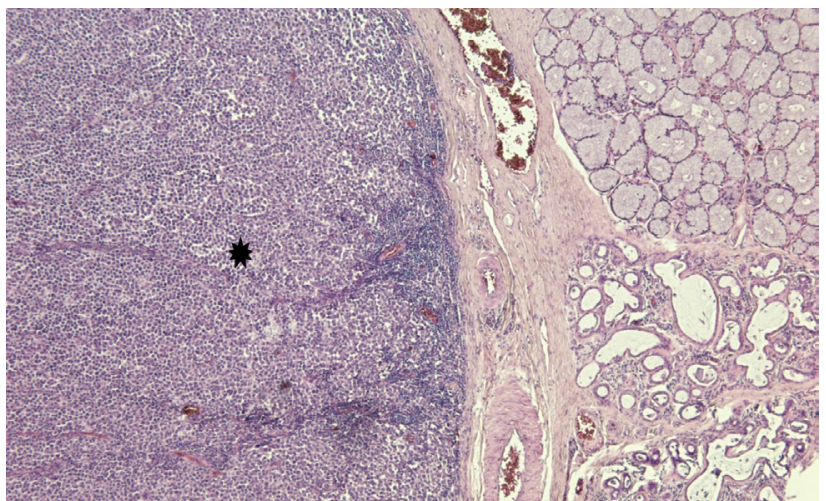

Figure 5. TVT cells beneath of serosal glands (star) in oral mucosa [H\&E, $\mathrm{x} 40]$.

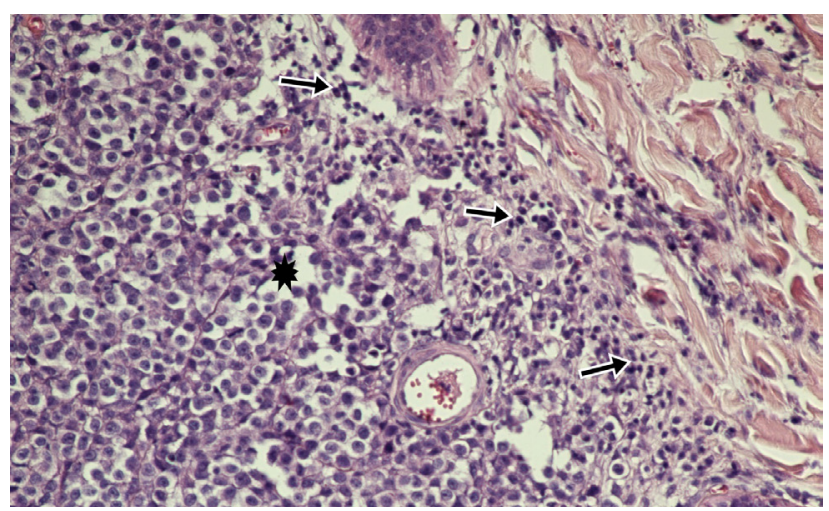

Figure 6. TVT cells between muscle fibers (star) and lymphocyte infiltrations (arrow), neck [H\&E, x200].

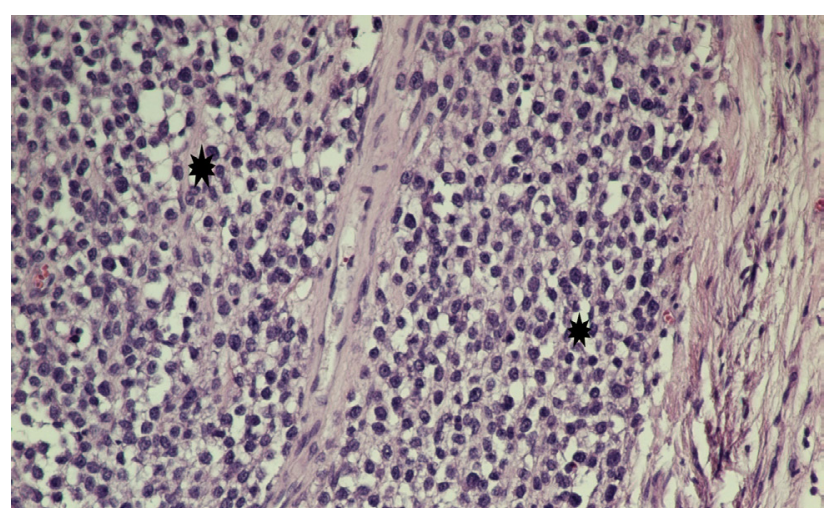

Figure 7.TVT cells between muscle fibers (stars), gluteal muscles [H\&E, x200].

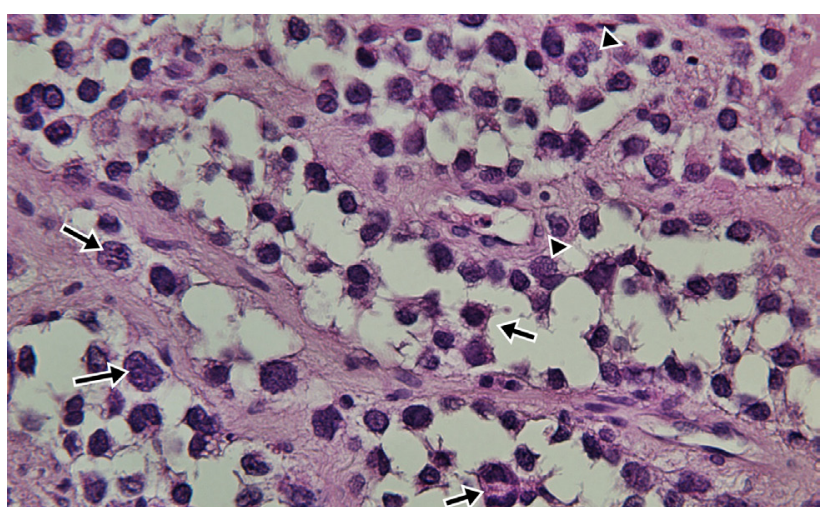

Figure 8. TVT infiltrating mammary glands (arrows) and mammary gland epitheliums (arrowheads) [H\&E]. 


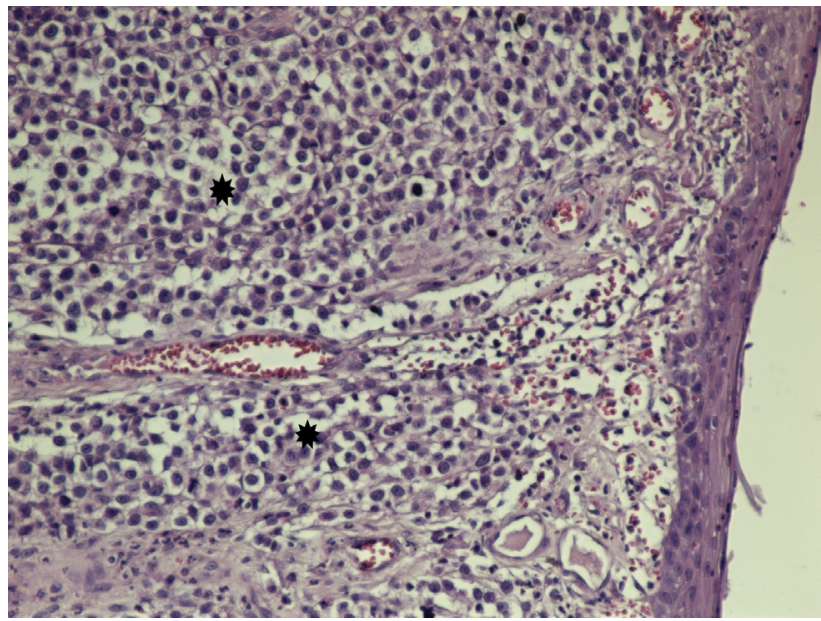

Figure 9. TVT cells in vagina (stars) [H\&E, $\mathrm{x} 400]$.

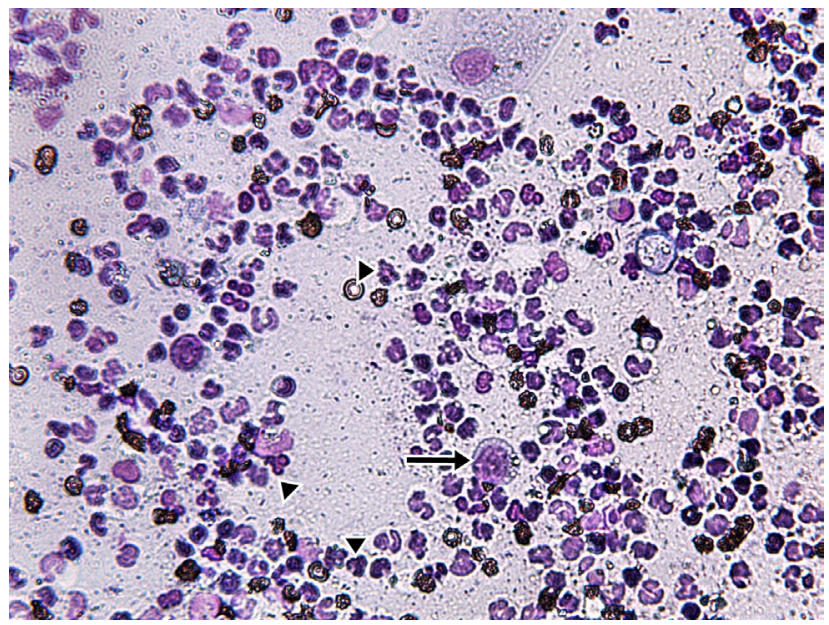

Figure 10. TVT cells (arrows) and neutrophyle leucocytes (arrowheads), vaginal smear [May-Grünwald-Giemsa staining, x400].

Table 1. Results of Blood Gas and Hematology.

\begin{tabular}{|c|c|c|c|c|c|}
\hline \multicolumn{3}{|c|}{ Blood Gas Analysis } & \multicolumn{3}{|c|}{ Hematology } \\
\hline Parameter & Results & Reference Values & Parameter & Results & Reference Values \\
\hline $\mathrm{pH}$ & 7.38 & $7.35-7.45$ & $\mathrm{WBC}\left(\mathrm{m} / \mathrm{mm}^{3}\right)$ & 18.89 & $6-17$ \\
\hline $\mathrm{pCO}_{2}(\mathrm{mmHg})$ & 36 & $40-50$ & $\operatorname{Lym}(\%)$ & 11.3 & $10-30$ \\
\hline $\mathrm{pO}_{2}(\mathrm{mmHg})$ & 34 & $30-42$ & Mon $(\%)$ & 2.4 & $2-10$ \\
\hline $\mathrm{Na}^{+}(\mathrm{mmol} / \mathrm{L})$ & 144 & $146-154$ & Gra (\%) & 86.3 & $50-80$ \\
\hline $\mathrm{K}^{+}(\mathrm{mmol} / \mathrm{L})$ & 4.6 & $3.8-5.3$ & $\operatorname{Lym}\left(\mathrm{m} / \mathrm{mm}^{3}\right)$ & 2.13 & $0.6-5.1$ \\
\hline $\mathrm{Ca}^{++}(\mathrm{mmol} / \mathrm{L})$ & 1.23 & $0.73-1.29$ & $\operatorname{Mon}\left(\mathrm{m} / \mathrm{mm}^{3}\right)$ & 0.45 & $0.1-1.7$ \\
\hline Glu (mg/dL) & 62 & $75-120$ & $\operatorname{Gra}\left(\mathrm{m} / \mathrm{mm}^{3}\right)$ & 16.31 & $3-13.6$ \\
\hline $\mathrm{Lac}(\mathrm{mmol} / \mathrm{L})$ & 2.4 & $1.15-2.20$ & $\mathrm{RBC}\left(\mathrm{M} / \mathrm{mm}^{3}\right)$ & 8.07 & $5.5-8.5$ \\
\hline Hct $(\%)$ & 52 & $37-55$ & MCV (fL) & 60.6 & $58-73$ \\
\hline $\mathrm{Ca}^{++}(7.4, \mathrm{mmol} / \mathrm{L})$ & 1.22 & $1.16-1.40$ & $\operatorname{Hct}(\%)$ & 48.9 & $35-55$ \\
\hline $\mathrm{HCO}_{-}(\mathrm{mmol} / \mathrm{L})$ & 21.3 & $17-28$ & $\mathrm{MCH}(\mathrm{pg})$ & 19 & $19.5-24.5$ \\
\hline $\mathrm{HCO} 3 \mathrm{std}(\mathrm{mmol} / \mathrm{L})$ & 21.3 & $17-24$ & $\mathrm{MCHC}(\mathrm{g} / \mathrm{dL})$ & 31.4 & $28-40$ \\
\hline TCO2 (mmol/L) & 22.4 & $18-29$ & RDW & 11.5 & $8-12$ \\
\hline BEecf (mmol/L) & -3.8 & $+/-5$ & $\mathrm{Hb}(\mathrm{g} / \mathrm{dL})$ & 15.4 & $10-18$ \\
\hline $\mathrm{BE}(\mathrm{B})(\mathrm{mmol} / \mathrm{L})$ & -3.2 & $+/-5$ & $\operatorname{PLT}\left(\mathrm{m} / \mathrm{mm}^{3}\right)$ & 525 & $120-600$ \\
\hline $\mathrm{SO}_{2 \mathrm{c}}(\%)$ & 64 & 78-86 & MPV (fL) & 7.8 & $5-12$ \\
\hline THbc (g/dL) & 16.1 & $9.8-15.4$ & Pct $(\%)$ & 0.41 & --- \\
\hline
\end{tabular}

\section{DISCUSSION}

TVT is frequently seen in dogs in a period when the sexual activity is high. Especially dogs in estrus are at the highest risk. There are no breed, sex and age predisposition for TVT. Although the disease can be seen in the dogs of all ages, many times it occurs in 2-5-year old animals [4]. In this report, the dog is not sexually active because she is spayed. Since the dog is 10 year old, she is above TVT risk range. This points out that either TVT had been developed and the dog has been infected for a long time or contaminated by sniffing or licking not by coupling.

TVT's malignancy can increase in some cases, although TVT is known as a benign tumor [11]. Prevalence of metastases was found fairly low in the studies (5-17\%) [9]. Metastases are occurred generally via mechanical extensions of the primary tumor [15] 
Table 2. Serum biochemical parameters.

\begin{tabular}{ccc}
\hline \multicolumn{3}{c}{ Serum Biochemical Parameters } \\
\hline Analyses & Results & Reference Values \\
\hline BUN (mg/dL) & 7 & $5.6-11.8$ \\
Creatinin (mg/dL) & 0.4 & $0.5-1.5$ \\
SGOT (UI/L) & 40 & $10-88$ \\
SGPT (UI/L) & 22 & $10-88$ \\
ALP (UI/L) & 152 & $20-150$ \\
LDH (UI/L) & 378 & $50-495$ \\
T. Bilirubin (mg/dL) & 0.8 & $0.1-0.6$ \\
Phosphore(mg/dL) & 4.4 & $2.2-5.5$ \\
Albumin (g/dL) & 2.6 & $2.3-3.8$ \\
Cholesterol (mg/dL) & 288 & $125-270$ \\
Triglyceride (mg/dL) & 49 & $20-112$ \\
\hline
\end{tabular}

or as a result of auto- or hetero- transplantation from external genital organs [4]. Metastases to mammary region [10-12], to subcutaneous region [8], to brain, to eye [5], to lung [16], to uterus, to ovary [1], to liver, to spleen [6] have been reported.
One the most important factor in TVT cases' metastasis is dog's immune system. Various immune mechanisms limit the progression of the tumor in the dogs which have a strong immunity whereas, in the dogs which have a weak immunity tumor can cause new metastatic tumor foci with malignant transformation. Especially in young dogs tumor is excessively tended to metastasis $[6,9,11]$. Furthermore, Laporte $e t$ al. [7] reported a TVT case metastasized to cutaneous, rostral face, gingiva in the 8-month old bitch.

TVT cases are often located in genital organs and it's metastases are rarely seen when compared to other tumors. In this case report, metastases to cervical tissue, neck skin, oropharyngeal mucosa and gluteal muscles, mammary lobes are found. In conclusion, even if a bitch is acyclic, TVT can be developed and the risk of it's disseminated metastases must be considered. Moreover, since the masses have not regresed for a long time, this situation may be related to severe immunosupression in the bitch.

Declaration of interest. The authors report no conflicts of interest. The authors alone are responsible for the content and writing of the paper.

\section{REFERENCES}

1 Bastan A., Acar D.B. \&Cengiz M. 2008. Uterine and ovarian metastasis of transmissible venereal tumor in a bitch. Turkish Journal of Veterinary and Animal. 32(1): 65-66.

2 Birhan G. \&Chanie M. 2015. A review on canine transmissible venereal tumor: from morphologic to biochemical and molecular diagnosis. Academic Journal of Animal Diseases. 4(3): 185-195.

3 Chikweto A., Kumthekar S., Larkin H., Deallie C., Tiwari K.P., Sharma R.N. \& Bhaiyat M.I. 2013. Genital and extragenital canine transmissible venereal tumor in dogs in Grenada, West Indies. Open Journal of Veterinary Medicine. 3: 111-114.

4 Das U. \& Das A.K. 2000. Review of canine transmissible venereal sarcoma. Veterinary Research Communications. 24(8): 545-556.

5 Ferreira A.J.A., Jaggy A., Varejäo A.P., Ferreira M.L.P., Correia J.M.J., Mullas J.M., Almeida O., Oliveira P. \& Prada J. 2000. Brain and ocular metastases from a transmissible venereal tumour in a dog. Journal of Small Animal Practice. 41(4): 165-168.

6 Kose A.M., Cizmeci S.U., Aydin I., Dinc D.A., Maden M. \& Kanat O. 2013. Disseminated metastatic transmissible venereal tumour in a bitch. Eurasian Journal of Veterinary Sciences. 29(1): 53-57.

7 Laporte C.M., Jaffe T., Loeffler D., Lewis T.P. \& Schick A.E. 2016. Multifocal metastatic cutaneous and mucosal transmissible venereal tumour in a female puppy. Veterinary Record Case Reports. 4(1): e000285.

8 Lopes P.D., dos Santos A.C.A.A. \& Silva J.E.S. 2015. Canine transmissible venereal tumor in the genital area with subcutaneous metastases in the head - case report. Revista Portuguesa de Ciências Veterinárias. 110(593-594): 120-123.

9 Martins M.I., Ferreira S.F. \& Gobello C. 2005. The canine transmissible venereal tumor: etiology, pathology, diagnosis and treatment. Recent Advances in Small Animal Reproduction. A1233-0405.

10 Nak D., Misırlıglu D., Nak Y., Seyrek-Intas K. \& Tek H.B. 2004. Bir köpekte meme metastazlı transmissible venereal tümör olgusu. Veteriner Bilimleri Dergisi. 20(1): 99-102.

11 Oruc E., Sağlam Y.S., Cengiz M. \& Polat B. 2011. Bir köpekte bulaşıcı venereal tümör meme metastazının ince iğne aspirasyonu ile sitolojik teşhisi ve vincristine sülfat ile tedavisi. Atatürk Üniversitesi Veteriner Bilimleri Dergisi. 6(1): 63-69. 
H. Alkan, F. Satilmis, M.E. Alcigir, M.B. Kivrak \& I. Aydin. 2017. Clinicopathological Evaluation of Disseminated Metastases of Transmissible Venereal Tumor in a Spayed Bitch. Acta Scientiae Veterinariae. 45(Suppl 1): 227.

12 Ozyurtlu N., Bademkıran S., Unver O., Yıldız F. \& Icen H. 2008. Dişi bir köpekte transmissible venereal tümörün abdominal ve subkutan inguinal bölgeye metastazı. Dicle Üniversitesi Veteriner Fakültesi Dergisi. 1(2): 48-51.

13 Park M.S., Kim Y., Kang M.S., Oh S.Y., Cho D.Y., Shin N.S. \& Kim D.Y. 2006. Disseminated transmissible venereal tumor in a dog. Journal of Veterinary Diagnostic Investigation. 18(1): 130-133.

14Purohit G. 2008. Canine transmissible venereal tumor: a review. The Internet Journal of Veterinary Medicine. 6(1): 1-7. 15 Stockmann D., Ferrari H.F., Andrade A.L., Lopes R.A., Cardoso T.C. \& Luvizotto M.C. 2011. Canine transmissible venereal tumors: aspects related to programmed cell death. Brazilian Journal of Veterinary Pathology. 4(1): 67-75.

16 Varughese E.E., Singla V.K., Ratnakaran U. \& Gandotra V.K. 2012. Successful management of metastasis of transmissible venereal tumour to lung and mammary region. In: Proceedings of the 7th International Symposium on Canine and Feline Reproduction - ISCFR(Whistler, Canada). 